
w Instytucie Slawistyki PAN, absolwent Filologii Białoru-

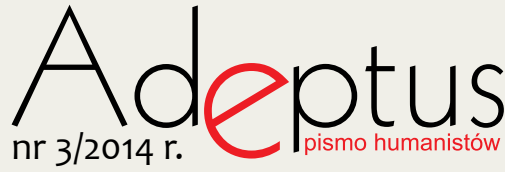
skiej i Filologii Polskiej UW. Autor ponad 40 artykułów oraz monografii: Dialektologia białoruska (Warszawa 2012, razem z N. Barszczewską), Gwary białoruskie na Łotwie $w$ rejonie krasławskim. Studium socjolingwistyczne (Warszawa 2008, wydanie białoruskie: Wilno-Białystok 2012). Tematyka badawcza: dialektologia, socjolingwistyka, język białoruski i gwary białoruskie w państwach bałtyckich i obwodzie kaliningradzkim, językowe pogranicza Białorusi, polski język północnokresowy

Mirosław Jankowiak

\title{
Sprawozdanie z konferencji Polyslav XVII (Kijów 11-14 września 2013 roku)
}

W dniach 11-14 września 2013 roku odbyła się w Kijowie kolejna, już siedemnasta, coroczna międzynarodowa konferencja Polyslav organizowana przez Europejskie Stowarzyszenie Młodych Slawistów. Konferencję tę można uznać za młodzieżowy odpowiednik Kongresu Slawistów, który odbywa się raz na cztery lata (ostatni miał miejsce w Mińsku w sierpniu 2013 roku). W 2012 roku Polyslav odbył się w Zurichu w Szwajcarii, a na organizatora konferencji we wrześniu 2014 roku został wybrany Uniwersytet im. Loránda Eötvösa w Budapeszcie.

Pierwsza konferencja Polyslavu miała miejsce na Uniwersytecie w Konstancji w październiku 1997 roku, a jej inicjatorami byli Björn Wiemer (Uniwersytet w Konstancji) i Markus Giger (Uniwersytet w Zurichu). Założeniem pomysłodawców było nawiązanie szerszej współpracy i wymiana wiedzy pomiędzy slawistami z krajów słowiańskich oraz badaczami języków słowiańskich z państw niemieckojęzycznych. Wynikało to z dużej różnicy w podejściu badawczym i wykorzystywanych metodologiach przez osoby z Europy Wschodniej i Zachodniej. Artykuły pokonferencyjne są publikowane co roku. W Kijowie podjęto decyzję o podniesieniu rangi zbioru pokonferencyjnego poprzez przekazywanie każdej publikacji niezależnym recenzentom, co z czasem umożliwi periodykowi (mającemu już kilkunastoletnią tradycję) znalezienie się na listach ERIH-a czy Scopus. 
Zgodnie z tradycją miejsce kolejnej konferencji wybierane jest drogą głosowania. We wrześniu 2013 roku organizatorem była Katedra Współczesnego Języka Ukraińskiego Instytutu Filologii Kijowskiego Uniwersytetu Państwowego im. Tarasa Szewczenki. Językoznawcy reprezentowali łącznie 11 państw (Bułgaria, Czechy, Macedonia, Niemcy, Polska, Rosja, Serbia, Słowacja, Słowenia, Szwajcaria oraz Ukraina).

Tak jak w poprzednich latach konferencja Polyslavu nie miała tytułu przewodniego i nie dotyczyła określonego obszaru badawczego. Młodzi slawiści prezentowali tematy badawcze, którymi aktualnie się zajmują. Umożliwiło to szersze zapoznanie się nie tylko z różnymi metodologiami, ale również ze slawistycznymi trendami w badaniach językoznawczych prowadzonych w różnych krajach i nierzadko znacznie się różniących. Łącznie zakwalifikowano 68 referatów, najwięcej wygłoszono w języku polskim (25), rosyjskim (14), angielskim (12) i ukraińskim (11). Nie zabrakło też języka słoweńskiego, serbskiego, czeskiego czy bułgarskiego. Po raz pierwszy w 17-letniej historii Polyslavu został wygłoszony referat w języku białoruskim. Zaprezentowane referaty dotyczyły zarówno językoznawstwa diachronicznego, jak i synchronicznego. Odnosiły się do różnych języków - białoruskiego, bułgarskiego, czeskiego, polskiego, rosyjskiego, serbskiego, słowackiego, słoweńskiego i ukraińskiego. Młodzi badacze prezentowali różne zagadnienia z zakresu dialektologii, socjolingwistyki, etnolingwistyki, historii języków słowiańskich, językoznawstwa porównawczego, semantyki, kontaktów językowych, językoznawstwa strukturalnego itd. O znaczeniu i aktualności prowadzonych badań świadczy fakt, że po wielu referatach odbyła się intensywna dyskusja, w której uczestniczyli nie tylko referenci, ale także pracownicy Instytutu Filologii (w tym pracownicy kijowskiej polonistyki) oraz studenci. Ożywione dyskusje naukowe wywoływały nie tylko różnice w podejściu metodologicznym (różne szkoły etnolingwistyczne czy w zakresie semantyki językoznawczej), ale nawet spory wynikające $z$ aspektów politycznych - jak uznawanie (bądź nie) przez bułgarskich językoznawców macedońskiego za odrębny język.

Organizatorzy konferencji nie tylko bardzo dobrze przygotowali się logistycznie do Polyslavu (pomoc studentów, w tym miejscowych polonistów), ale również zorganizowali wiele wycieczek po najciekawszych miejscach Kijowa, jak Sobór Wołodomirski, Sobór Mądrości Bożej (Sofia Kijowska), Skansen w Pirogowie, Złota Brama i wiele innych. Uczestnicy konferencji mogli zatem zapoznać się kulturą materialną i duchową narodu ukraińskiego. 


\section{Summary:}

The paper is a conference report. Young Slavists meet each other every year at the Polyslav conference. The previous meeting took place in Kiev and was organized by the Institute of Philology of the Taras Shevchenko National University in Kiev (Department of the Modern Ukrainian Language). Young linguists from 11 countries presented 68 reports associated with Slavic languages. The reports were related to almost all areas of linguistics.

\section{Keywords:}

conference report, Polyslav, Slavic studies, Slavic languages, young Slavists

\section{Streszczenie:}

Tekst jest sprawozdaniem z konferencji. Młodzi slawiści co roku spotykają się na konferencji Polyslav. Ostatnia z nich została zorganizowana przez Instytut Filologii Państwowego Uniwersytetu Kijowskiego im. Tarasa Szewczenki (Katedra Współczesnego Języka Ukraińskiego) w Kijowie. Młodzi slawiści z 11 krajów zaprezentowali 68 referatów opisujących języki słowiańskie. Referaty dotyczyły prawie wszystkich dziedzin językoznawstwa.

\section{Słowa kluczowe:}

sprawozdanie z konferencji, Polyslav, badania slawistyczne, języki słowiańskie, młodzi slawiści 